REVIEW ARTICLE

\title{
Palliative Care in the Emergency Department
}

\begin{abstract}
The Emergency Department (ED) is the place where people most frequently seek urgent care. For patients living with chronic disease or malignancy who may be in a crisis, this visit may be pivotal in determining the patients' trajectory. There is a large movement in education of emergency medicine physicians, hospitalists, and intensivists from acute aggressive interventions to patient-goal assessment, recognizing last stages of life and prioritizing symptom management. Although the ED is not considered an ideal place to begin palliative care, hospital-based physicians may assist in eliciting the patient's goals of care and discussing prognosis and disease trajectory. This may help shift to noncurative treatment. This article will summarize the following: identification of patients who may need palliation, discussing prognosis, eliciting goals of care and directives, symptom management in the ED, and making plans for further care. These efforts have been shown to improve outcomes and to decrease length of stay and cost. The focus of this article is relieving "patient" symptoms and family distress, honoring the patient's goals of care, and assisting in transition to a noncurative approach and placement where this may be accomplished.
\end{abstract}

\section{Introduction}

Although not considered an ideal place to begin palliative care, in reality the Emergency Department (ED) is the most frequent place where urgent care is sought. Whether there are gaps in the outpatient setting or failure to predict and plan for crisis intervention, the ED experience may be pivotal in determining a patient's trajectory. The culture of emergency medicine to provide stabilization of acute medical urgencies is now shifting to a more patient-

\section{Definition of Palliative Care}

Palliative care is the relief of symptoms including pain that interferes with the quality of life. Whether patients have cancer or heart failure, they have already been undergoing noncurative symptom management in addition to their curative therapies. There must be ongoing reevaluations of life-prolonging interventions so as to determine when they no longer prolong life but instead prolong suffering and unwanted side effects. Palliative care is not the same as hospice or end-of-life care. The latter involves aggressive symptom management in patients with chronic diseases who are on a progressive and rapid decline to death. In hospice care, patients generally have less than a six-month life expectancy. goal-centered culture. There has been a large movement to educate emergency physicians on end-of-life care and improve palliative care in emergency medicine, leading to clinical practice guidelines. ${ }^{1}$ In reality, because of the acute symptoms that are often accompanied by significant emotional overtones and disposition issues, a hospitalist or intensivist is quickly consulted. Many patients present with serious and unrelieved symptoms such as pain, dyspnea, nausea, and vomiting that were not well controlled in the outpatient setting. The ED or hospital may be the only option for them to receive intravenous (IV) fluids or medications, as well as immediate access for acute imaging or access to specialists, for example, radiation oncologists. Even if the patient's goals are clearly nonaggressive, the patient may arrive in the ED because of family distress over symptoms.

\section{Characteristics of Patients Needing a Palliative Care Consult}

Patients with a serious, life-threatening illness and one or more of the following need a palliative care consult (see Sidebar: Definition of palliative care): ${ }^{2}$

- Not Surprised

You would not be surprised if the patient died in the next 12 months

- Bounce-Backs

The patient makes more than one ED visit or hospital admission for the same condition within several months

- Uncontrolled Symptoms

An ED visit is prompted by difficult-tocontrol physical or emotional symptoms

- Functional Decline

There is decline in function or worsening of feeding intolerance, unintentional weight loss, or caregiver distress

- Increasingly Complicated

Complex long-term care needs require more support.

Other patients that may benefit from early hospital medicine or palliative care consult include transfers from a longterm-care facility; patients with metastatic or locally advanced, incurable cancer; hospice patients; patients with out-ofhospital cardiac arrest; advanced dementia patients; and frail, elderly patients with poor functional status.

Adults with chronic illnesses often visit an ED several times in their last year of life. A study of patients older than age 65 years by Smith et al revealed $75 \%$ visited an ED in the last 6 months of life and $51 \%$ in the last month, many with repeat visits. ${ }^{3}$ The transition from curative to noncurative symptom management may greatly change the hospital trajectory of care. Here is the opportunity to initiate further goals of care that may change future plans. Research supports early palliative care in the ED to improve quality of life as well as to reduce costs that may have been associated with alternate treatments. ${ }^{4-6}$ Discussions surrounding goals and plan of care, symptom management, and aggressive pain control are 
some of the cornerstones of palliative care. Some additional benefits from early palliative care interventions in the ED include resource management, improved satisfaction for patients and their families, improved outcomes, decreased length of stay, less use of intensive care units and less cost, and increased appropriate direct hospice consults. ${ }^{5,7-10}$

\section{Goal-Oriented Patient Assessment}

The first imperative is to find out why the patient is in the ED and to perform a rapid assessment of their palliative care needs. Emergency medicine physicians can begin goal-directed assessments and plans that can help avoid unwanted treatments, inappropriate resource expenditure, and undue suffering. See Sidebar: Goals-of-Care Discussion in the Emergency Department for advice regarding goals of care discussions. ${ }^{11}$

\section{Advanced \\ Directives/Capacity}

Eliciting goals from patients who are unable to converse can be challenging. Are they temporarily very sick or do they lack decision-making capability? Capacity is defined by the ability of the patient to have a process to understand the options and their ramifications. Surrogate decision makers must be reminded to do their best to express the patient's wishes and not their own. It should be ascertained if there are advanced directives. These forms, signed by the patient and witnesses, are twofold. They can be helpful in that they designate a surrogate decision maker, and hopefully, this person knows the patient well and has had a prior conversation regarding the patient's wishes. The other aspect of the directives may be instructional but is prone to misinterpretation. There is often a section indicating whether the person would want "heroic measures" taken if there were no hope of recovery.

\section{Goals-of-Care Discussion in the Emergency Department ${ }^{\mathrm{a}}$}

1. Communicate prognosis clearly: "Hope for the best, prepare for the worst."

a. Explain your clinical assessment of what is wrong and what you expect the outcome will be.

b. It is often difficult to engage the patient and family in a discussion of a poor prognosis. Make it clear if the process is not curable. "It appears that X is not possible. What we can do is hope that he does not suffer."

2. Engage the patient/surrogate by eliciting their goals of care with open-ended questions.

a. "What are you hoping for?"

b. "What are you afraid of?"

c. "What is quality of life to you?"

d. "What is important to you right now?"

e. "What is the meaning of a good death vs bad death? Is there any type of treatment you hope to avoid?"

3. Choose words wisely.

a. Avoid negative statements that may make the patient feel abandoned:

i. "Do you want us to stop aggressive care?"

b. Highlight the patient's best interest:

i. "Let us discuss how we can help you meet your goals."

ii. "We are here to ensure that you receive the treatment that is best for you and in line with your personal goals."

4. Determine a treatment plan that is in line with the patient's wishes.

a. Summarize your patient's goals:

i. "From what I understand, your goal is to

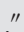

b. Initiate a plan of action:

i. "In order to meet this goal, we can

c. Encourage the patient/surrogate to advocate for their wishes:

i. "If you feel that the treatment you are receiving is no longer worthwhile, not enough, or causes you too much suffering, we can change our plan at any time."

Adapted and reprinted with permission from Clinics in Geriatric Medicine 2013 Feb;29(1), Rosenberg M, Lamba S, Misra S, Palliative medicine and geriatric emergency care: challenges, opportunities, and basic principles, 1-29, Copyright 2013, with permission from Elsevier. DOI: http://dx.doi.org/10.1016/j.cger.2012.09.006.

Here is an opportunity for the patient or surrogate to elaborate what is important to the patient, what no hope means, and what recovery means. It may be helpful to verify a do-not-resuscitate (DNR) status in the event of a pulseless state or cardiac arrest, so as to allow natural death. But it is also important to distinguish when the patient does have a pulse and is otherwise doing relatively well; we can continue to treat reversible situations. When patients and their families state they want "everything," do not presume this translates to full resuscitation. This could mean they want every measure that has the potential to prolong life, or it could mean they want every measure taken to provide maximum relief of suffering.

If death is not imminent and the patient is having a reversible setback, this coincides with "limited interventions" on a POLST (physician order for life-sustaining treatment) form. POLST is a multistate form that includes orders, signed by the patient and physician, documenting choices regarding resuscitation, medical interventions, and some treatment options including artificial nutrition. Reassure the family that a DNR applies when someone does not have a pulse and is essentially dead, but if a patient has a pulse and is otherwise doing relatively well, treating the acute problem, such as pneumonia, makes sense.

Prognostication, and informing loved ones of the likelihood and severity of outcomes, especially those related to function, may help guide their choices. Most of the data on outcomes of cardiopulmonary resuscitation (CPR) come from the National Registry of Cardiopulmonary Resuscitation, which analyzed more than 14,000 CPR attempts in adults from 2000 to 2002 in US hospitals. ${ }^{12}$ This revealed that $17 \%$ of these patients survived to be discharged. Many of the survivors suffered neurologic and functional decline, and only half were able to return home. A meta-analysis of CPR outcomes from 49 studies of almost 10,000 patients showed survival to discharge of $13 \%$ to $15 \% .{ }^{13}$ A more recent study showed some improvement in survival rates after $\mathrm{CPR}$, with the rate of survival to discharge improving from $13.7 \%$ in 2000 to $22.3 \%$ in 2009 and a corresponding decrease in neurologic disability rate from $32.9 \%$ 
to $28.1 \%{ }^{14}$ Although it is postulated that faster response times, improved quality of resuscitation efforts, and refined protocols for postresuscitation care all contributed to these favorable outcomes, the role of palliative care and goals-ofcare discussions leading to more POLST completions and DNR orders in frail populations was suggested to play a role as well. These survival percentages are overinflated given that they include a population of patients with cardiac ischemia-related ventricular tachycardia/ fibrillation, which may double the chance of CPR survival. Asystole and pulseless electrical activity are more common in the sick and frail elderly and are associated with only a 10\% CPR survival to discharge rate. ${ }^{13}$ Factors that predict failure to survive to discharge included sepsis the day before the CPR event, serum creatinine $>1.5 \mathrm{mg} / \mathrm{dL}$, metastatic cancer, dementia, and dependent status. In another study, the success rate in sub- jects with metastatic cancer was 7.8\%. In dialysis patients it was $14 \%$, but only $3 \%$ of the survivors were alive at 6 months. ${ }^{15}$ Among patients in the intensive care unit, survival to discharge was only $2.2 \%$. There was no neurologic outcome included. ${ }^{16}$ It is a physician's responsibility to properly educate and inform patients regarding the potential outcomes of attempted CPR based on functional status and comorbid conditions and to clarify patient preferences for the worst-case

\begin{tabular}{|l|l|l|l|}
\hline \multicolumn{2}{|l|}{ Table 1. Reversible causes of dyspnea } \\
\hline Cause & \multicolumn{1}{|c|}{ Underlying condition } & \multicolumn{1}{|c|}{ Emergent solution } & \multicolumn{1}{c|}{ Contraindications } \\
\hline Pleural effusion & Malignancy, CHF, infection & Thoracentesis & $\begin{array}{l}\text { Prior patient discomfort with procedure, } \\
\text { INR }>1.5, \text { platelets }<50,000\end{array}$ \\
\hline Ascites & Malignancy, CHF, cirrhosis & Paracentesis & $\begin{array}{l}\text { Prior patient discomfort, INR }>1.5 \text { and } \\
\text { platelets }<50,000 \text { (if not cirrhotic) }\end{array}$ \\
\hline Fluid overload & Renal failure, CHF & Diuresis & Electrolyte imbalance \\
\hline Anemia & $\begin{array}{l}\text { Malignancy, chronic illness, } \\
\text { hemorrhage, clotting deficiency }\end{array}$ & Transfusion & Patient refusal or volume overload \\
\hline Excess secretions & $\begin{array}{l}\text { Active phase of dying, } \\
\text { pneumonia, malignancy }\end{array}$ & $\begin{array}{l}\text { Anticholinergic drugs, scopolamine 1 mg patch } \\
\text { or glycopyrrolate } 0.2 \mathrm{mg} \mathrm{SC/IV} \mathrm{every} \mathrm{3h,} \mathrm{gentle} \\
\text { suctioning }\end{array}$ & Patient discomfort, delirium \\
\hline
\end{tabular}

$\mathrm{CHF}=$ congestive heart failure; $\mathrm{h}$ = hours; INR = international normalized ratio; IV = intravenous; $\mathrm{SC}=$ subcutaneous.

\begin{tabular}{|c|c|c|c|}
\hline Severity & Tolerance & Agent & Titration \\
\hline \multirow[t]{2}{*}{ Mild dyspnea } & Opioid naïve & $\begin{array}{l}\text { Hydrocodone + acetaminophen (Norco) } 2.5-5 \mathrm{mg} / 325 \mathrm{mg} \\
\text { PO every 2-4h } \\
\text { Codeine + acetaminophen (Tylenol \#3) } 30 \mathrm{mg} / 300 \mathrm{mg} \text { PO } \\
\text { every } 2-4 \mathrm{~h} \\
\text { Morphine/roxanol } 2.5-5 \mathrm{mg} \text { PO/liquid suspension every } 2 \mathrm{~h} \\
\text { or } 1-1.5 \mathrm{mg} \text { IV every } 15 \mathrm{~min}\end{array}$ & $\begin{array}{l}\text { May increase dose by } 25 \%-50 \% \text { every } \\
12-24 \mathrm{~h} \text { for oral dose, every } 30 \text { min for IV } \\
\text { dose } \\
\text { Titrate to sedation level or respiratory rate } \\
10-12\end{array}$ \\
\hline & Opioid tolerant & $\begin{array}{l}\text { Use patient's home regimen. If only using as-needed dosing } \\
\text { at home, change to intravenous formulations or scheduled } \\
\text { dosing }\end{array}$ & $\begin{array}{l}\text { Titrate dose upward or increase frequency } \\
\text { to patient comfort, monitoring for change in } \\
\text { mental status and respiratory depression }\end{array}$ \\
\hline \multirow[t]{2}{*}{ Severe dyspnea } & Opioid naïve & $\begin{array}{l}\text { Morphine/roxanol } 5 \mathrm{mg} \text { PO/liquid suspension every 2-4h or } \\
1.5 \mathrm{mg} \text { IV every } 15 \mathrm{~min} \\
\text { Oxycodone + acetaminophen (Percocet) } 5 \mathrm{mg} / 325 \mathrm{mg} \text { PO } \\
\text { every } 2-4 \mathrm{~h} \\
\text { Hydromorphone } 1-2 \mathrm{mg} \text { PO every } 2-4 \mathrm{~h} \text { or } 0.2-0.5 \mathrm{mg} \mathrm{IV} \\
\text { every } 15 \mathrm{~min}\end{array}$ & $\begin{array}{l}\text { Titrate to sedation level or respiratory rate } \\
10-12\end{array}$ \\
\hline & Opioid tolerant & $\begin{array}{l}\text { Use patient's home regimen } \\
\text { If only using as-needed dosing at home, change to IV } \\
\text { formulations or scheduled dosing. Can give } 10 \% \text { of total daily } \\
\text { dose equivalent IV every } 30 \text { min for breakthrough dyspnea }\end{array}$ & $\begin{array}{l}\text { Titrate dose upward or increase frequency } \\
\text { to patient comfort, monitoring for change in } \\
\text { mental status and respiratory depression }\end{array}$ \\
\hline \multirow[t]{2}{*}{$\begin{array}{l}\text { Active phase of } \\
\text { death }\end{array}$} & Opioid naïve & $\begin{array}{l}\text { Morphine } 1 \mathrm{mg} \text { IV or } \\
\text { Hydromorphone } 0.2 \mathrm{mg} \text { IV every } 15 \mathrm{~min}\end{array}$ & $\begin{array}{l}\text { Titrate dose upward to patient comfort, } \\
\text { consider continuous infusion for intractable } \\
\text { dyspnea }\end{array}$ \\
\hline & Opioid tolerant & $\begin{array}{l}\text { Morphine } 1.5 \mathrm{mg} \text { IV or } \\
\text { Hydromorphone } 0.5 \mathrm{mg} \text { IV every } 15 \mathrm{~min}\end{array}$ & $\begin{array}{l}\text { Titrate dose upward to patient comfort, } \\
\text { consider continuous infusion for intractable } \\
\text { dyspnea }\end{array}$ \\
\hline
\end{tabular}

$\mathrm{h}=$ hours; IV = intravenous; $\mathrm{PO}=$ oral. 
scenario. If a patient would still want CPR despite a high chance of a poor outcome, the physician should offer to discuss goals of care and perhaps time-limited trials, in the event that the patient was dependent on machines.

\section{Trajectories}

To help patients and families feel comfortable with their decisions, the clinician must understand common death trajectories and prognoses.

There are four common disease trajectories: sudden death, terminal illness, organ failure, and frailty. ${ }^{17}$ The common example of terminal illness is malignancy. Patients often function fairly well until the last few months or year. In organ failure, such as congestive heart failure or chronic obstructive pulmonary disease, the death trajectory is slow and dotted with frequent exacerbations and near resolution, but the patients often do not return to their previous function. They eventually die but may suddenly die during an exacerbation. This is the situation where families will say, "But the doctor told us he was going to die when he was in the intensive care unit last year." Patients who are frail are already at a low functioning state and slowly deteriorate.

In terms of organ failure like congestive heart failure, there are many online prognostic tools, such as the Seattle Heart Failure Model. ${ }^{18}$ This enables physicians to enter patient data into a system that calculates statistics on survival and the impact of medical interventions with the click of a button. By taking a moment to type in a few patient characteristics, a physician in the ED can compute a mean life expectancy, which could help identify patients who may benefit more from a palliative care consult than from a prolonged hospital admission. ${ }^{19}$

A simple screening tool for prognosis of cancer patients is the Eastern Cooperative Oncology Group Performance Status (ECOG-PS) scale. ${ }^{20}$ Scores range from 0-5, with 0 indicating a fully functional patient and 5 indicating death. Those with a score of 1 are limited in their functioning but can still work and go about their daily activities. A score of 2 indicates the ability to walk but not work, 3 indicates being confined to a bed/chair more than $50 \%$ of the day, and 4 indicates being completely bedbound. This quick, numerical assessment based on mobility can allow physicians to rapidly triage cancer patients. Patients with an ECOG-PS score of 3 or 4 are considered too weak to benefit from chemotherapy. If this is new information for the patient, it should trigger a palliative care consult and goals-of-care discussion.

Similarly, the Palliative Performance Scale is a grid chart and can be used to assess the prognosis of our frail patient population by evaluating 1) mobility, 2) level of disease and impact on activity, 3) capacity for self-care, 4) oral intake, and 5) mental status on a scale of $0 \%$ to $100 \%{ }^{21}$ Among patients with a score of $50 \%$ or less, only $10 \%$ will survive more than 6 months, warranting a palliative care consult. ${ }^{22,23}$

The bottom line is that if patients are unable to take care of themselves, especially if they are bedbound, this poor functional status portends poor survival. A poor functional state precludes the use of treatment that requires patient participation, such as chemotherapy or radiation therapy. For example, if patients cannot come in to the infusion center, they cannot continue to get transfusions or infusions. Many institutions have implemented a process for generating mortality predictions from risk factors at the time of admission. This prognostic information helps predict death and other serious adverse events. This information can help patients and their families in future decision making and can help the medical team in formulating appropriate care plans. ${ }^{24}$

\section{Symptom Management in the Emergency Department Dyspnea}

Discomfort in breathing is a subjective sensation rather than a diagnosis and is very common among many patients with chronic illness, including those with cancer, chronic obstructive pulmonary disease, HIV/AIDS, congestive heart failure, stroke, amyotrophic lateral sclerosis (ALS), and dementia. ${ }^{25}$ It is most often caused by an underlying medical condition, but it may arise from anxiety. A pulse oximeter reading alone is not an indicator of dyspnea; rather, careful examination of the patient and appreciation of their distress via facial expression, level of anxiety, ability to

\begin{tabular}{|l|c|}
\hline \multicolumn{2}{|l|}{ Table 3. Methadone conversion ${ }^{\mathrm{a} 29}$} \\
\hline $\begin{array}{l}\text { Daily } \\
\text { morphine dose }\end{array}$ & $\begin{array}{l}\text { Conversion between } \\
\text { morphine:methadone }\end{array}$ \\
\hline$\leq 100 \mathrm{mg}$ & $3: 1$ \\
\hline $101-300 \mathrm{mg}$ & $5: 1$ \\
\hline $301-600 \mathrm{mg}$ & $10: 1$ \\
\hline $601-800 \mathrm{mg}$ & $12: 1$ \\
\hline $801-1000 \mathrm{mg}$ & $15: 1$ \\
\hline$\geq 1001 \mathrm{mg}$ & $20: 1$ \\
\hline
\end{tabular}

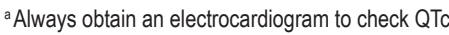
interval before initiating methadone treatment Avoid in those with QTc prolongation.

speak in full sentences, and accessory muscle use can assist in determining the level of discomfort. A normal oxygen saturation and lack of accessory muscle use should not preclude treatment of the patient's described complaint.

The first-line treatment for this sensation is medications from the opioid class of drugs. Although its mechanism is mostly unknown, its benefit is clearly recognized. This treatment, in addition to oxygen, can be initiated in the ED while reversible causes of dyspnea are sought. See Table 1 for reversible causes of dyspnea and some treatment options. If the patient requires frequent thoracenteses or paracenteses, the patient may be a candidate for a permanent catheter allowing intermittent drainage of fluid at home. See Table 2 for elaboration on opioid treatment options. One must monitor acetaminophen doses from all sources and avoid morphine, codeine, hydrocodone, and oxycodone in patients with significant renal dysfunction. Fentanyl and methadone are safe in renal failure and dialysis patients. Fentanyl is also safe in liver failure, whereas other opioids will need a downward adjustment. When opioids are titrated upward, a change in mental status and alertness occurs before hypoventilation.

Because anxiety often plays a role in dyspnea, a clinician may consider an anxiolytic to accompany opioid treatment. Longer-acting agents such as the benzodiazepine clonazepam are often used starting at $0.25 \mathrm{mg}$ orally every 12 hours. Lorazepam (0.5-1 mg orally every 4 to 6 hours) is also available in liquid and suppository forms, which is helpful if a patient has difficulty swallowing pills. Use the intravenous form if a quicker onset of action is needed. 


\section{Pain}

Most patients living with life-limiting chronic illness who come into the ED are already on a pain regimen, often on dosages that exceed common practice. Using the patient's current pain regimen and adjusting it to meet symptomatic relief is an important skill. Facility with titrating common narcotics will allow for adequate control of this prevalent symptom.

Basics of Pain Management in Patients with Chronic Life-Limiting Illness

Many patients are on a combination of opioids that can make understanding their pain requirements confusing. Converting all opioids to the oral morphine equivalent allows physicians to titrate medications effectively and confidently.

\section{Equivalents and Titration}

\section{of Analgesics}

Below is a quick way to remember approximate and equivalent IV/oral (PO) conversions between morphine (less potent) and hydromorphone (more potent), the two most common opioids used in the hospital setting: ${ }^{26,27}$

- $10 \mathrm{mg}$ morphine IV $30 \mathrm{mg}$ morphine PO (1:3)
- $1.5 \mathrm{mg}$ hydromorphone IV $7.5 \mathrm{mg}$ hydromorphone PO (1:5)

- $1.5 \mathrm{mg}$ hydromorphone IV $30 \mathrm{mg}$ morphine PO (1:20)

- $1.5 \mathrm{mg}$ hydromorphone IV $10 \mathrm{mg}$ morphine IV (1:6)

- $7.5 \mathrm{mg}$ hydromorphone PO $30 \mathrm{mg}$ morphine PO (1:4).

Calculate the total daily dose of oral morphine to gauge each patient's pain medication requirement, and adjust each medication per the following guidelines:

- If converting between products, decrease the equivalent dose by $0 \%$ to $25 \%$

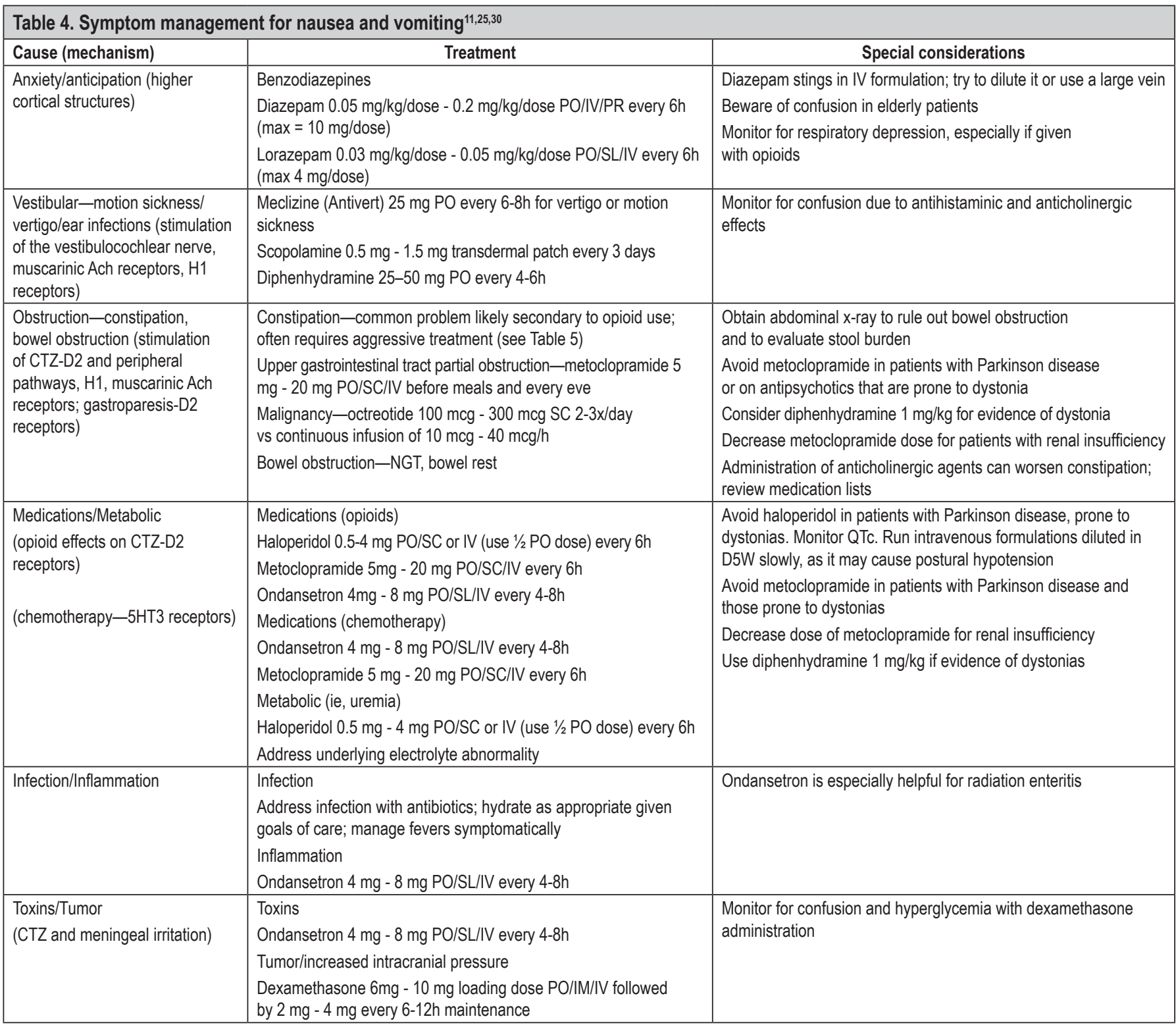

$5 \mathrm{HT} 3$ = serotonin subunit; $\mathrm{Ach}=$ acetylcholine; $\mathrm{CTZ}=$ chemoreceptor trigger zone; $\mathrm{D2}=$ dopamine $2 ; \mathrm{h}=$ hours; $\mathrm{H1}$ = histamine $1 ; \mathrm{D} 5 \mathrm{~W}=$ dextrose $5 \%$ in water; IM = intramuscular; $\mathrm{IV}=$ intravenous; $\mathrm{NGT}=$ nasogastric tube; $\mathrm{PO}=$ oral; $\mathrm{PR}=$ per rectum; $\mathrm{QTC}=$ corrected $\mathrm{QT}$ interval; $\mathrm{SC}=$ subcutaneous; $\mathrm{SL}$ = sublingual. 
for poorly managed pain or to $50 \%$ for adequately treated pain

- If titrating an orally dosed agent, shortacting agents can be increased $25 \%$ to $50 \%$ for mild to moderate pain and 50\% to $100 \%$ for moderate to severe pain, up to a maximum of every-2-hour dosing

- Fentanyl patches can only be titrated every 3 days, and methadone can only be titrated every 4 to 7 days. Find out from the patient when the dose was last increased before adjusting these medications

- In titration of an intravenous or subcutaneous infusion, increase the basal dose by $25 \%$ to $100 \%$ on the basis of severity of pain. Consider an extra loading dose of $50 \%$ to $100 \%$ of the hourly dose first, before increasing the infusion rate for better pain control if symptoms are particularly severe.

If the patient is on methadone or a fentanyl patch ${ }^{28,29}$

- the dose of morphine in milligrams $\mathrm{PO}$ in 24 hours/ 2 is approximately the dose of fentanyl patch in micrograms in opioid-tolerant populations

- Do not use this conversion in opioid naïve or older populations. Instead, start at the lowest dose of fentanyl and titrate upward.

See Table 3 for methadone conversion.

With fentanyl and methadone titration, we recommend conferring with someone with expertise in pain medications. This person may also suggest other pain adjuvants such as nonsteroidal anti-inflammatory drugs, gabapentin for neuropathic pain, lidocaine patches, bisphosphonates, and local radiation for bony pain.

\section{Nausea and Vomiting}

Nausea and vomiting are very common complaints with multiple etiologies that make the choice of treatment clear once the underlying culprit is identified. A common mnemonic is A VOMIT: ${ }^{25,30}$
A: Anxiety/Anticipation
V: Vestibular
O: Obstruction
M: Medications/Metabolic
I: Infection/Inflammation
T: Toxins/Tumor

Always look for reversible causes. To select the appropriate drug treatment, identify the most likely cause and receptor pathway of the nausea and choose an antagonist to the receptor. Coadministration of a chemoreceptor trigger zone antiemetic for the initial 3 to 5 days of opioid therapy is recommended to prevent drug-induced nausea. If the symptoms do not improve over 3 to 4 days, opioid rotation is another option. ${ }^{31}$ See Table 4 for symptom management for nausea and vomiting.

\section{Bowel Obstruction}

Postsurgical adhesions and compression from tumors are two common causes of bowel obstruction that affect people at the end of life. These pathologic changes impair the movement of gastrointestinal contents causing uncomfortable abdominal distention and abdominal colic. Bowel obstruction leads to hypoxia in the bowel wall and bacterial overgrowth.

\begin{tabular}{|c|c|}
\hline Symptom & Treatment \\
\hline \multirow[t]{4}{*}{$\begin{array}{l}\text { Vomiting from } \\
\text { obstruction }\end{array}$} & $\begin{array}{l}\text { Antisecretory agents: } \\
\text { octreotide } 100 \mathrm{mcg} \text { - } 200 \mathrm{mcg} \text { SC 2-4x/day vs continuous infusion of } \\
10 \mathrm{mcg} / \mathrm{h}-40 \mathrm{mcg} / \mathrm{h} \\
\text { glycopyrrolate } 0.2 \mathrm{mg} \mathrm{SC} \text { every } 3 \mathrm{~h}\end{array}$ \\
\hline & $\begin{array}{l}\text { Steroids } \\
\text { dexamethasone } 6 \mathrm{mg} \text { - } 10 \mathrm{mg} \text { loading PO/IM/IV dose followed by } 2 \mathrm{mg} \text { - } 4 \mathrm{mg} \\
\text { every 6-12h maintenance dose }\end{array}$ \\
\hline & $\begin{array}{l}\text { Antidopaminergic agents } \\
\text { haloperidol } 0.5 \mathrm{mg} \text { - } 4 \mathrm{mg} \mathrm{PO} / \mathrm{SC} \text { or IV (use } 1 / 2 \mathrm{PO} \text { dose) every } 6 \mathrm{~h} \\
\text { metoclopramide } 5 \mathrm{mg}-20 \mathrm{mg} \mathrm{PO} / \mathrm{SC} / \mathrm{IV} \text { every } 6 \mathrm{~h}\end{array}$ \\
\hline & Nasogastric tube to decompress the stomach if in line with goals of care \\
\hline Gastric spasm & $\begin{array}{l}\text { Anticholinergic drugs } \\
\text { scopolamine } 0.5 \mathrm{mg}-1.5 \mathrm{mg} \text { transdermal patch every } 3 \text { days } \\
\text { glycopyrrolate } 0.2 \mathrm{mg} \mathrm{SC} \text { every } 3 \mathrm{~h}\end{array}$ \\
\hline \multirow[t]{2}{*}{$\begin{array}{l}\text { Outlet } \\
\text { obstruction }\end{array}$} & $\begin{array}{l}\text { Dexamethasone } 4 \mathrm{mg} \text { - } 8 \mathrm{mg} \text { PO/IV loading with } 4 \mathrm{mg} \text { - 8mg PO/IV 2x/day } \\
\text { maintenance to decrease gut wall edema }\end{array}$ \\
\hline & $\begin{array}{l}\text { Palliative stenting, percutaneous venting gastrostomy, or surgical bypass if in line } \\
\text { with goals of care to provide symptomatic relief of intractable symptoms }\end{array}$ \\
\hline $\begin{array}{l}\text { Fecal } \\
\text { impaction }\end{array}$ & Manual disimpaction, bowel regimen (see Table 6) \\
\hline
\end{tabular}

$\mathrm{h}=$ hours; IM = intramuscular; IV = intravenous; $\mathrm{PO}=$ oral; $\mathrm{SC}=$ subcutaneous.

\section{Table 6. Constipation management $\mathrm{t}^{\mathrm{a}}$}

\begin{tabular}{|l|l|}
\hline Agent/dose & \multicolumn{1}{|c|}{ Mechanism } \\
\hline Lactulose $15 \mathrm{~mL}$ - $30 \mathrm{~mL}$ every $12-24 \mathrm{~h}$ & Osmotic laxative \\
\hline Polyethylene glycol $17 \mathrm{~g}$ in 8 oz water every $24 \mathrm{~h}$ & Osmotic laxative \\
\hline Sorbitol $15 \mathrm{~mL}$ - $30 \mathrm{~mL}$ every $12-24 \mathrm{~h}$ & Osmotic laxative \\
\hline Magnesium citrate 120 - $240 \mathrm{~mL} \times 1$ & $\begin{array}{l}\text { Saline laxative, can be used with glycerin in } \\
\text { an enema }\end{array}$ \\
\cline { 2 - 2 } & Avoid in renal failure \\
\hline Milk of magnesia $30 \mathrm{~mL}$ every $12-24 \mathrm{~h}$ & Saline laxative that increases peristalsis \\
\cline { 2 - 2 } & Avoid in renal failure \\
\hline Bisacodyl $5 \mathrm{mg}$ - $15 \mathrm{mg} \times 1$ & Stimulant laxative \\
\hline Senna 2-3 tabs every $12-24 \mathrm{~h}$ & Stimulant laxative \\
\hline \multirow{2}{*}{ Docusate $100 \mathrm{mg}-250 \mathrm{mg}$ every 12-24h } & Surface laxative to soften stool \\
\cline { 2 - 2 } & Use with stimulant laxative \\
\hline Mineral oil/tap water enemas & Softens stool and rinses it out \\
\cline { 2 - 2 } & May be uncomfortable for some patients \\
\hline
\end{tabular}

$h=$ hours.

a Adapted and reprinted with permission from Clinics in Geriatric Medicine 2013 Feb;29(1), Rosenberg M, Lamba S, Misra S, Palliative medicine and geriatric emergency care: challenges, opportunities, and basic principles, 1-29, Copyright 2013, with permission from Elsevier. DOI: http://dx.doi.org/10.1016/j.cger.2012.09.006. 
An increase in vasoactive intestinal peptide hormone leads to hypersecretion, which stimulates nausea and vomiting. ${ }^{25}$ Untreated, bowel obstruction can lead to overwhelming sepsis and multiorgan failure. Clinicians may be misled by a history of diarrhea that can result from stool leaking around an impaction causing obstruction. The complaint of nausea can be an indication of early obstruction as well. An abdominal x-ray can therefore be very helpful in evaluating a terminally ill patient with complaints of nausea, vomiting, diarrhea, constipation, or obstipation. A rectal examination is used to rule out fecal impaction. If hard, impacted stool is found, manual disimpaction is warranted first. See Table 5 and Table 6 for symptom management of bowel issues. ${ }^{32}$

\section{Constipation}

Constipation is a very common issue among patients with terminal illnesses. Given that many are on a variety of opioids, it is important to ensure that they are placed on an adequate bowel regimen to prevent the uncomfortable effect of narcotic-induced ileus. A variety of differ- ent agents can be used either by mouth or rectally to stimulate the bowels. In general, stimulants work best to prevent opioid-induced constipation. Minimally, a patient on opioids should be on senna regularly. The addition of stool softeners, bisacodyl, and nightly prune juice is often helpful. Talk with your patient regarding the patient's preferred method of administration and what has worked in the past.

\section{Other Emergent Conditions Massive Hemorrhage}

If the patient is already enrolled in hospice, hopefully a preemptive conversation has occurred, including planning and goals of care, to avoid unwanted emergency interventions. Bleeding may occur when a malignancy erodes into a blood vessel. Quickly review any bleeding risks and search for treatable factors. Drugs such as aspirin, nonsteroidal antiinflammatory drugs, anticoagulants, and antiplatelet drugs should be stopped. Infusion of platelets or blood factors can be discussed if the bleed is not believed to be fatal. Compress, when possible, with dark towels and apply hemostatic dressings for superficial wounds. Consider interventional radiology consult for internal bleeding if death is not imminent, if this aligns with the patient's goals of care.

\section{Spinal Cord Compression}

New or worsening back pain in a cancer patient who is otherwise doing well warrants a full exam and imaging. Most patients have preceding back pain that worsens, or they may suddenly be unable to walk or may lose continence. This is an emergency, and time is of the essence. Steroids are started immediately with dexamethasone $100 \mathrm{mg}$ intravenous then $24 \mathrm{mg}$ orally every 6 hours for 3 days. Radiation therapy is administered and steroids tapered accordingly. Magnetic resonance imaging of the entire spine is done to look for other lesions and spine stability. Using the Patchell criteria, if there is a solitary spine metastasis, the patient's life expectancy is greater than 3 months, and the paralysis is less than 2 days, then immediate surgery could be undertaken. Up to $70 \%$ of these patients regain the ability to walk. ${ }^{33,34}$ Radiation oncology should be quickly consulted to make a scheduled plan depending on the number

\begin{tabular}{|c|c|c|}
\hline Changes at the end of life & Symptoms/signs & Management \\
\hline \multirow[t]{3}{*}{ Decreased oral intake } & \multirow[t]{3}{*}{$\begin{array}{l}\text { Dry mucous membranes, } \\
\text { refusing to eat or drink }\end{array}$} & $\begin{array}{l}\text { Do not start IV fluids, as dehydration and starvation states may stimulate endorphin } \\
\text { release at the end of life as a natural response to provide comfort }\end{array}$ \\
\hline & & Moisten lips with petroleum, use artificial saliva/mouth sponges and ice chips \\
\hline & & Pleasure feeding with small bites of what the patient desires \\
\hline \multirow{4}{*}{$\begin{array}{l}\text { Cardiac and renal } \\
\text { dysfunction }\end{array}$} & \multirow{4}{*}{$\begin{array}{l}\text { Cold extremities, pale } \\
\text { skin, dark urine, oliguria, } \\
\text { hypotension, tachycardia }\end{array}$} & Do not bolus IV fluids, as unlikely to change outcome and may worsen urinary retention \\
\hline & & Consider foley catheter if urinary retention is causing patient discomfort \\
\hline & & Consider keeping patient off a cardiac monitor, limit vital sign checks \\
\hline & & Provide blankets, focus on keeping patient comfortable \\
\hline \multirow[t]{4}{*}{ Neurologic dysfunction } & \multirow{4}{*}{$\begin{array}{l}\text { Drowsiness, disorientation, } \\
\text { inability to follow commands, } \\
\text { incontinence, mumbling, } \\
\text { inability to close eyes }\end{array}$} & Normalize the situation, explain to family the changes surrounding the end of life \\
\hline & & Encourage family/friends at bedside to talk to and comfort the patient \\
\hline & & Provide artificial tears if eyes remain open \\
\hline & & May occasionally need haloperidol or lorazepam for restlessness \\
\hline \multirow[t]{2}{*}{ Increased oral secretions } & \multirow[t]{2}{*}{ "Death rattle," gurgling } & Avoid deep suctioning \\
\hline & & $\begin{array}{l}\text { Consider scopolamine } 1 \mathrm{mg} \text { patch vs glycopyrrolate at } 0.2 \mathrm{mg} \text { SC/IV every } 3 \mathrm{~h} \text { vs } \\
\text { atropine } 1 \% \text { ophthalmic solution } 1-2 \text { drops SL every } 4 \mathrm{~h} \text { to dry secretions }\end{array}$ \\
\hline \multirow[t]{3}{*}{ Respiratory dysfunction } & \multirow{3}{*}{$\begin{array}{l}\text { Cheyne-Stokes respiration, } \\
\text { agonal breathing, irregular } \\
\text { respiratory rate }\end{array}$} & Normalize the situation \\
\hline & & Reassure family \\
\hline & & Consider morphine if patient shows increased work of breathing \\
\hline \multirow[t]{4}{*}{ Pain/terminal delirium } & \multirow{4}{*}{$\begin{array}{l}\text { Facial grimacing, moaning, } \\
\text { agitation, hallucinations }\end{array}$} & Look for reversible causes \\
\hline & & $\begin{array}{l}\text { Consider opioids vs benzodiazepine (lorazepam elixir } 1 \mathrm{mg}-2 \mathrm{mg} \text { every } 1 \mathrm{~h} \text { as } \\
\text { needed) or neuroleptics (haloperidol } 0.5 \mathrm{mg}-2 \mathrm{mg} \text { SC/IVIPO every } 1 \mathrm{~h} \text { as needed) }\end{array}$ \\
\hline & & If renal failure, avoid morphine, which may cause muscle twitching \\
\hline & & Encourage family/friends at bedside to comfort and soothe patient \\
\hline
\end{tabular}

$\mathrm{h}=$ hours; IV = intravenous; $\mathrm{PO}=$ oral; $\mathrm{SC}$ = subcutaneous; $\mathrm{SL}=$ sublinguinal. 
of lesions and life expectancy. Patients receive much pain relief from radiation. Superior Vena Cava Syndrome

Rapid progression of a thoracic malignancy leading to respiratory distress with facial and arm swelling warrants endovascular stent placement as an effective immediate intervention if aligned with the patient's goals. ${ }^{35}$ Dexamethasone IV/PO can be initiated at $6 \mathrm{mg}$ every 6 hours. If the tumor is chemosensitive, patients may benefit from chemotherapy if it aligns with their goals and with their functional status.

\section{Recognizing and Actively Treating the Dying Patient}

The terminal phase of illness can be emotionally challenging yet comforting if those involved feel that the patient's goals have been met. Early recognition and realization will help with management needs. The patient may have an irreversible decline that has increased in rapidity or a sentinel event, such as massive stroke or decision to withdraw life support. Communication, gentle yet swift, may allow time for closure. The first and foremost palliative care cornerstone is ensuring the best quality of what is left of the patient's shortened life. All families are different in handling such an emotional situation and may need some guidance in how to achieve a peaceful outcome. If there is time, a hospitalist should be consulted for admission to the hospital so that the patient may be in a private room. The patient should be involved as long as possible or as long as $\mathrm{s} /$ he is willing. To begin this potentially frightening topic, one could start with, "Most people faced with this bad situation have concerns or specific questions." Also inquire if the patient would like some spiritual support, which can usually be arranged quickly through the on-call hospital chaplain or the patient's congregation.

Some signs of the last few hours include decrease in appetite, interaction, level of consciousness, and urine output. Next signs are hemodynamic changes with low blood pressure, tachycardia, and mottled extremities. Respiratory changes ensue with rattling secretions, irregular breathing pattern, then apnea, and finally cessation of the heartbeat. See Table 7 for treatment of the actively dying patient.

\section{The Hospice Patient in the Emergency Department}

This does not always translate into a patient wanting to revoke hospice. The clinician must ascertain why the patient is in the ED. More times than not, the patient came to the ED for symptom management. Other possibilities include families that are unable to handle symptoms or emotional burden. Early referral to the hospitalist for admission and to the palliative care team for symptom management may be indicated for symptoms unrelieved in the ED. Also, referral to social services for additional help at home or possible placement may be of benefit. The patient's hospice needs to be notified of the patient's admission, and staff from the hospice will continue to see the patient daily while $s /$ he is in the hospital, under the short-term inpatient benefit.

If it is important for the patient to be in his or her own home, we must do everything possible to help palliate the acute problem and then get the patient back to his or her environment. If the family is unable to take care of the patient at home, enlisting more help or consideration for the patient to receive hospice in the nursing home is another option.

\section{Summary}

- The primary goal of palliative care is to relieve suffering

- Palliative care starting in the ED is to help patients and their families focus on their goals of care

- The clinician must evaluate the disease trajectory and overall function of the patient to help guide further treatment options

- When developing the next steps, the clinician must be honest yet gentle in discussing prognosis

- The shift from curative to noncurative treatment improves patient satisfaction and decreases use of valuable resources

- Challenges with advanced directives include vague wording, dramatic change in health after completion, and conflicts between family members

- To help guide therapy, focus on what the patient wants or would want
- The out-of-hospital DNR is a physician's order, signed by the patient and physician

- Nausea is best treated by identifying the offending agent and receptor involved and choosing the antagonist to that receptor

- The patient's home pain regimen must be taken into consideration when pain medications are prescribed in the ED

- Use the Patchell criteria in patients with metastatic spinal cord compression to see if they would benefit from surgical decompression

- The arrival of the hospice patient in the ED does not translate to revoking hospice but, more likely, to symptom management

- Most people want to die symptom free and in familiar surroundings. It may be possible to manage the symptoms and arrange the transition back to home from the ED

- If the family still cannot take care of the patient, additional help should be arranged for home or an alternative place to live while the patient continues to receive hospice care.

\section{Disclosure statement}

The author(s) have no conflicts of interest to disclose.

\section{Acknowledgment}

Leslie Parker, ELS, provided editorial assistance.

\section{References}

1. Chan G, Bryant EN, Lamba S, Weissman DE Quest TE, Knox TH. Clinical practice guidelines: a technical assistance resource from the IPAL-EM project [Internet]. New York, NY: The IPAL-EM Project, Center to Advance Palliative Care; 2011 [cited 2013 Nov 13]. Available from: http://ipal.capc.org/downloads/ipal-emclinical-practice-guidelines.pdf.

2. Quest TE, Bryant EN, Waugh D, Grudzen C, Weissman DE. Palliative care ED screening tool: a technical assistance resource from the IPAL-EM project [Internet]. New York, NY: The IPAL-EM Project, Center to Advance Palliative Care: 2011 [cited 2013 Nov 13]. Available from: http://ipal.capc.org/downloads/ipal-empalliative-care-ed-screening-tool.pdf.

3. Smith AK, McCarthy E, Weber $E$, et al. Half of older Americans seen in emergency department in last month of life; most admitted to hospital, and many die there. Health Aff (Millwood) 2012 Jun;31(6):1277-85. DOI: http://dx.doi.org/10.1377/hlthaff.2011.0922 Erratum in: Health Aff (Millwood) 2012 Jul:31(7):1650. DOI: http://dx.doi.org/10.1377/ hlthaff.2012.0619.

4. Quest TE, Asplin BR, Cairns CB, Hwang U, Pines JM. Research priorities for palliative and end-of-life care in the emergency setting. 
Acad Emerg Med 2011 Jun;18(6):e70-6. DOI: http://dx.doi.org/10.1111/j.15532712.2011.01088.x.

5. Penrod JD, Deb P, Dellenbaugh C, et al. Hospital-based palliative care consultation: effects on hospital cost. J Palliat Med 2010 Aug;13(8):973-9. DOl: http://dx.doi. org/10.1089/jpm.2010.0038.

6. Temel JS, Greer JA, Muzikansky A, et al. Early palliative care for patients with metastatic non-small-cell lung cancer. N Engl J Med 2010 Aug 19;363(8):733-42. DOI: http://dx.doi. org/10.1056/NEJMoa1000678.

7. Penrod JD, Deb P, Luhrs C, et al. Cost and utilization outcomes of patients receiving hospital-based palliative care consultation. J Palliat Med 2006 Aug;9(4):855-60. DOI: http:// dx.doi.org/10.1089/jpm.2006.9.855. Erratum in: J Palliat Med 2006 Dec;9(6):1509. DOl: http://dx.doi.org/10.1089/jpm.2006.9.1509.

8. Meier DE, Beresford L. Fast response is key to partnering with the emergency department. J Palliat Med 2007 Jun;10(3):641-5. DOI: http:// dx.doi.org/10.1089/jpm.2007.9959.

9. Stone SC, Mohanty SA, Grudzen C, Lorenz KA, Asch SM. Emergency department research in palliative care: challenges in recruitment. J Palliat Med 2009 Oct;12(10):867-8. DOI: http:// dx.doi.org/10.1089/jpm.2009.0139.

10. Beemath A, Zalenski RJ. Palliative emergency medicine: resuscitating comfort care? Ann Emerg Med 2009 Jul;54(1):103-5. DOI: http://dx.doi.org/10.1016/j.annemergmed.2009.02.011.

11. Rosenberg M, Lamba S, Misra S. Palliative medicine and geriatric emergency care: challenges, opportunities, and basic principles. Clin Geriatr Med 2013 Feb;29(1):1-29. DOI: http:// dx.doi.org/10.1016/j.cger.2012.09.006.

12. Peberdy MA, Kaye W, Ornato JP, et al. Cardiopulmonary resuscitation of adults in the hospital: A report of 14720 cardiac arrests from the National Registry of Cardiopulmonary Resuscitation. Resuscitation 2003 Sep;58(3):297308. DOI: http://dx.doi.org/10.1016/S03009572(03)00215-6.

13. Ebell MH, Becker LA, Barry HC, Hagen M Survival after in-hospital cardiopulmonary resuscitation: a meta-analysis. J Gen Intern Med 1998 Dec;13(12):805-16. DOI: http://dx.doi. org/10.1046/j.1525-1497.1998.00244.X.

14. Girotra S, Nallamothu BK, Spertus JA, Li Y, Krumholz HM, Chan PS; American Heart Association Get with the Guidelines-Resuscitation Investigators. Trends in survival after in-hospital cardiac arrest. N Engl J Med 2012 Nov 15;367(20):1912-20. DOI: http://dx.doi. org/10.1056/NEJMoa1109148.
15. Hijazi F, Holley JL. Cardiopulmonary resuscitation and dialysis: outcome and patients' views. Semin Dial 2003 Jan-Feb;16(1):51-3 DOI: http://dx.doi.org/10.1046/j.1525139X.2003.03012.x

16. Reisfield GM, Wallace SK, Munsell MF, Webb FJ, Alvarez ER, Wilson GR. Survival in cancer patients undergoing in-hospital cardiopulmonary resuscitation: a metaanalysis. Resuscitation 2006 Nov:71(2):152-60. DOI: http://dx.doi.org/10.1016/j.resuscitation.2006.02.022.

17. Lunney JR, Lynn J, Hogan C. Profiles of older Medicare decedents. J Am Geriatr Soc 2002 Jun;50(6):1108-12. DOI: http://dx.doi org/10.1046/j.1532-5415.2002.50268.x.

18. Seattle heart failure monitor [Internet]. Seattle, WA: University of Washington; 2006-2012 [cited 2014 Jan 15]. Available from: http:// depts.washington.edu/shfm/index.php.

19. Levy WC, Mozaffarian D, Linker DT, et al. The Seattle Heart Failure Model: prediction of survival in heart failure. Circulation 2006 Mar 21;113(11):1424-33. DOI: http://dx.doi. org/10.1161/CIRCULATIONAHA.105.584102.

20. Callin SE, Bennett MI. Assessment of mobility. In: Walsh TD, Caraceni AT, Fainsinger R, et al, editors. Palliative medicine. 1st ed. Philadelphia, PA: Saunders Elsevier; 2009. p 359-63.

21. Wilner LS, Arnold R. \# 125 the palliative performance scale (PPS). Fast facts and concepts [Internet]. Milwaukee, WI: EPERC, Medical College of Wisconsin; 2004 Nov [updated 2009 Apr; cited 2013 Nov 14]. Available from: www.eperc.mcw.edu/EPERC/FastFactsIndex/ ff_125.htm.

22. Glare PA, Sinclair CT. Palliative medicine review: prognostication. J Palliat Med 2008 Jan-Feb;11(1):84-103. DOI: http://dx.doi. org/10.1089/jpm.2008.9992

23. Head B, Ritchie CS, Smoot TM. Prognostication in hospice care: can the palliative performance scale help? J Palliat Med 2005 Jun;8(3):492502. DOI: http://dx.doi.org/10.1089/ jpm.2005.8.492.

24. Cowen ME, Strawderman RL, Czerwinski IL, Smith MJ, Halasyamani LK. Mortality predictions on admission as a context for organizing care activities. J Hosp Med 2013 May;8(5):22935. DOI: http://dx.doi.org/10.1002/jhm.1998.

25. Policzer JS, Sobel J. Management of selected nonpain symptoms of life-limiting illness. Hospice and Palliative Care Training for Physicians: A self-study program. 3rd edition, Unipac 4. Glenview, IL: American Academy of Hospice and Palliative Medicine; 2008.

26. Arnold R, Weismann DE. \# 036 calculating opioid dose conversions. Fast facts and concepts
[Internet]. Milwaukee, WI: EPERC, Medical College of Wisconsin; 2005 Jul [updated 2009 Mar; cited 2013 Nov 14]. Available from: www.eperc.mcw.edu/EPERC/FastFactsIndex/ ff_036.htm.

27. Bial A, Levine S. Assessment and treatment of physical pain associated with life-limiting illness. Hospice and Palliative Care Training for Physicians: A self-study program. 3rd edition, Unipac 3. Glenview, IL: American Academy of Hospice and Palliative Medicine; 2008.

28. Weissman DE. \# 002 converting to/from transdermal fentanyl, 2nd ed. Fast facts and concepts [Internet]. Milwaukee, WI: EPERC, Medical College of Wisconsin; 2005 Jul [updated 2009 Mar; cited 2013 Nov 14]. Available from: www.eperc.mcw.edu/EPERC/FastFactsIndex/ff_002.htm

29. Gazelle G, Fine PG. \# 075 methadone for the treatment of pain, 2nd ed. Fast facts and concepts [Internet]. Milwaukee, WI: EPERC, Medical College of Wisconsin; 2006 Jul [updated 2009 Apr; cited 2013 Nov 14]. Available from: www.eperc.mcw.edu/EPERC/FastFactsIndex/ ff_075.htm.

30. Hallenbeck JL. Palliative care perspectives. New York, NY: Oxford University Press, Inc; 2003.

31. Wood GJ, Shega JW, Lynch B, Von Roenn JH. Management of intractable nausea and vomiting at the end of life: "I was feeling nauseous all of the time ... nothing was working." JAMA 2007 Sep 12:298(10):1196-207. DOI: http://dx.doi.org/10.1001/jama.298.10.1196.

32. Portenoy RK, Ahmed E, Keilson YY. Cancer pain management: adjuvant analgesics (coanalgesics) [Internet]. New York, NY: UpToDate; 2013 Sep 25 [cited 2013 Nov 14]:[password required]. Available from: www.uptodate.com/ contents/cancer-pain-management-adjuvantanalgesics-coanalgesics.

33. Loblaw DA, Perry J, Chambers A, Laperriere NJ. Systematic review of the diagnosis and management of malignant extradural spinal cord compression: the Cancer Care Ontario Practice Guidelines Initiative's Neuro-Oncology Disease Site Group. J Clin Oncol 2005 Mar 20;23(9):2028-37. DOI: http://dx.doi. org/10.1200/JCO.2005.00.067

34. Patchell RA, Tibbs PA, Regine WF, et al. Direct decompressive surgical resection in the treatment of spinal cord compression caused by metastatic cancer: a randomised trial. Lancet 2005 Aug 20-26:366(9486):643-8.

35. Wan JF, Bezjak A. Superior vena cava syndrome. Emerg Med Clin North Am 2009 May;27(2):243-55. DOI: http://dx.doi. org/10.1016/j.emc.2009.01.003.

\section{Help}

One cannot help a man to come to accept his impending death if he remains in severe pain, one cannot give spiritual counsel to a woman who is vomiting, or help a wife and children say their goodbyes to a father who is so drugged that he cannot respond. 